\title{
Primary and bacterial production in sea ice in the northern Baltic Sea
}

\author{
Pia Haecky*, Agneta Andersson** \\ Department of Microbiology, Umeå University, 90187 Umeå, Sweden
}

\begin{abstract}
The temporal variation of ice primary and bacterial production along with ice algal, bacterial and heterotrophic flagellate biomass were studied at a coastal station in the northern Baltic Sea throughout the ice-covered period of 1996 (January to April). Ice core samples were taken every week and analyzed for abundance and production of different microorganisms. In addition, physical and chemical parameters were measured. The ice algae were limited by light during the first 3 mo of the study. The algal production showed a peak in the middle of April, which coincided with a marked increase in light availability. Shortly after that, the system became phosphorus depleted and primary production decreased rapidly. Bacterial biomass and production rates were relatively low and stable before the ice algal bloom. After the ice algal bloom, bacterial production increased rapidly, while the biomass remained low. The growth rate of small heterotrophic flagellates $(<10 \mu \mathrm{m})$, calculated from increase in biomass, was more than 1 order of magnitude higher than the bacterial production rate following the ice algal bloom. Thus, small heterotrophic flagellates were using food sources other than bacteria for growth after the ice algal bloom. On an annual basis, the ice algal and bacterial production accounted for $<1 \%$ and $<0.1 \%$ respectively of the total production (ice + pelagic) due to a short ice-covered season. During the ice-covered season, however, the ice algae accounted for $10 \%$ of the total algal production, while ice bacterial production was $0.2 \%$ of the total bacterial production.
\end{abstract}

KEY WORDS: Sea-ice P Primary production - Bacterial production - Heterotrophic flagellates - Nutrients Light

\section{INTRODUCTION}

Sea ice microbial communities are known to occur in both polar and temperate ice-covered regions including the Baltic Sea area (Horner 1985, Palmisano \& Garrison 1993, Norrman \& Andersson 1994, Ikävalko \& Thomsen 1997, Haecky et al. 1998). The sea ice microbial community consists of representatives from all trophic levels of the microbial food web and includes bacteria, algae, heterotrophic protozoa and small metazoa (Garrison 1991). Sea ice microbes successfully inhabit the surface, interior and the bottom of the ice (Horner et al. 1992). Ice algal growth rates are controlled by brine temperature and salinity, as well as by

Present addresses:

- Marine Biological Laboratory (University of Copenhagen) Strandpromenaden 5, 3000 Helsingør, Denmark.

E-mail: pia.haecky@micro.umu.se

- Marine Ecology, Department of Ecology and Environmental Science, Umeâ University, 90187 Umeå, Sweden the availability of light and nutrients (Cota et al. 1991). During ice formation hypersaline brine is produced, in which nutrients and other dissolved constituents of the seawater are concentrated. Subsequently, the brine drains into milli- to micrometer-sized pockets and channels throughout the ice matrix, where the chemical composition is controlled by sea ice temperature (Weeks \& Ackley 1986). Brine volume decreases with temperature, and salts contained within it are concentrated correspondingly. Bulk nutrient concentrations in newly formed sea ice are essentially equal to those in the water at the time of ice formation, while nutrient concentrations in older sea ice are influenced by brine drainage and by the activity of sea ice microbial communities (Dieckmann et al. 1991, Gleitz et al. 1995). The brine, which is the environment actually experienced by sea ice microorganisms, is thus fundamentally different from the pelagic environment. Brine channels contain large surface areas per brine volume. Salinity and nutrient concentrations can be extremely 
high but variable, depending on age and temperature of the ice. On the other hand, the light environment in sea ice habitats is more stable than that in planktonic habitats, since ice is not subject to large vertical displacements in the irradiance field. As a result, the sea ice provides an environment where ice algae can grow, while phytoplankton growth is severely limited by light, thus prolonging the growth season by at least 1 to 3 mo (Cota et al. 1991). During the winter months irradiances are low, which leads to light limitation and low light adaptation of ice algae. However, in late spring and early summer, light may cause photoinhibition of ice algae (Kirst \& Wiencke 1995). In annual sea ice, algae are limited by light at the beginning of the season and by inorganic nutrients later in the season, as these are usually consumed or drained out of the ice (Gosselin et al. 1990, Cota et al. 1991).

The length of the ice-covered season, as well as the growth season of sea ice algae, increases with latitude. At low latitudes the ice-covered season is short (1 to $3 \mathrm{mo}$ ) and it usually occurs during the darkest period of the year, while polar regions can be covered by ice all the year round. The contribution of the production within the ice, relative to the total (ice + pelagic) production is thus expected to vary through the season and with latitude. In recent studies in the Arctic and Antarctic Oceans, ice algae accounted for 3 to $57 \%$ and 20 to $33 \%$ of total annual primary production, respectively (Legendre et al. 1992, Kirst \& Wiencke 1995, Gosselin et al. 1997). In the central Arctic Ocean ice algal production during the summer months was found to contribute up to $57 \%$ of the entire primary production, while the algal contribution was only 2 to $5 \%$ in the surrounding regions. In an early study in the Beaufort Sea, sea ice production was estimated to constitute as much as $2 / 3$ of primary production during winter and early spring (Horner \& Schrader 1982). Thus, ice productivity, relative to pelagic productivity, shows a marked variation within and between different sea areas.

Every year, the northern Baltic Sea is ice-covered for 4 to $6 \mathrm{mo}$, while the southern Baltic Sea is more or less ice-free all year around. Diverse microbial communities have previously been found in the interior brine channels of the annual land-fast ice of the northern Baltic Sea (Norrman \& Andersson 1994, Ikävalko 1997), but the bacterial and algal production have not been measured before. In this study, we measured the magnitude of sea ice bacterial and algal production in order to estimate its contribution to the total production in the low productive region of the northern Baltic Sea. Sea ice productivity was compared to pelagic productivity at the same location during the ice-covered season and during the whole year. A carbon budget model of microbial carbon flows was created from measured stocks and rates.

\section{MATERIAL AND METHODS}

Sampling. Ice samples were collected weekly at a coastal station in the Gulf of Bothnia $\left(63^{\circ} 33^{\prime} 76^{\prime \prime} \mathrm{N}, 19^{\circ}\right.$ $50^{\prime} 74^{\prime \prime}$ E) throughout the ice-covered season, January to April 1996 (Fig. 1). On 2 occasions (13 and 26 March 1996), 6 stations were sampled along a $10 \mathrm{~km}$ westsoutheast transect from the coastal high frequency station to a station further offshore $\left(63^{\circ} 29^{\prime} 30^{\prime \prime} \mathrm{N}, 19^{\circ}\right.$ $56^{\prime}$ E). A stainless steel corer, $13 \mathrm{~cm}$ diameter (Franson, Luleå Technical High School, Sweden), powered by a motor, was used for ice sampling. Triplicate ice cores were routinely taken, measured and cut into 3 equal length sections (top, middle and bottom of the ice core). However, during the transect samplings ice cores were kept intact (12 March) or cut into 2 equal length sections (top and bottom of the ice core, 26 March). The ice fractions were transported back to the laboratory in acid-washed buckets, while keeping them dark and cold. In the laboratory, the samples were left for 10 to $20 \mathrm{~min}$ in order to collect drainage. The drainage consisted mainly of brine, since the time of collection was too short for any notable melting of the ice. This fraction will henceforth be called brine The brine was kept at $0^{\circ} \mathrm{C}$ until further processing Brine from the triplicate samples was pooled to a final volume of at least $80 \mathrm{ml}$ from each section. This was the minimum volume needed for the measurements of algal and bacterial production, chlorophyll a (chl a), bacterial and heterotrophic flagellate numbers and

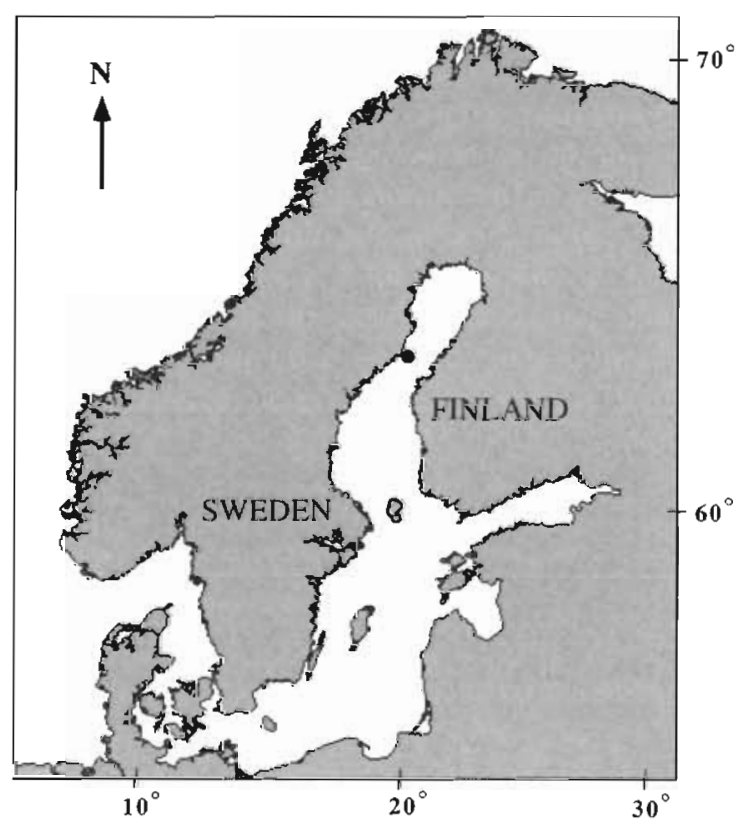

Fig. 1. Map of the Baltic Sea. sampling site 
inorganic nutrients. After collecting the brine, the remainder of the ice core was completely thawed for the determination of chl a, bacteria and heterotrophic flagellates. The remaining ice core was processed as soon as it was fully thawed and, like the brine, always kept at $0^{\circ} \mathrm{C}$. Whole ice core concentrations were determined by adding concentrations in the brine and the remaining ice cores in correct volumetric proportions, which are henceforth called ice concentrations. Stock and production values are given per ice volume or in areal units $\left(\mathrm{m}^{-2}\right)$. Data on pelagic variables were retrieved from a coastal monitoring station situated close to the high frequency station. At this station, samples from 0 to $20 \mathrm{~m}$ depth were taken throughout the year every 2 to 4 wk.

Nutrients and salinity. Nutrient samples were taken from the brine of the ice core sections and filtered through precombusted $\left(5 \mathrm{~h}\right.$ at $400^{\circ} \mathrm{C}$ ) Whatman $\mathrm{GF} / \mathrm{F}$ filters. The samples were analyzed immediately or frozen until analysis. Nutrient concentrations were determined using a TRAACS auto analyzer (Alfa Laval Bran and Luebbe TRAACS 800) and standard seawater procedures (Grasshoff et al. 1983). The nutrient concentrations are reported per volume of brine. Measuring inaccuracies (standard deviations of triplicates) for phosphate, nitrate + nitrite, ammonium, and silicate concentrations were $2.6,1.2,6.9$ and $1.3 \%$, respectively. Salinity was measured in brine water and in residual thawed ice cores, using a salinometer (AGE Instruments Inc., Model 2100).

Light. Photosynthetically active radiation (PAR, 400 to $800 \mathrm{~nm}$ ) was measured hourly in air and at each sampling occasion under the ice, using a spherical quantum meter (Li-Cor, Nebraska, USA). PAR under the ice was measured through a hole drilled in the ice $(15 \mathrm{~cm})$, with the sensor attached to a curved rod. The rod kept the sensor in an upright position under the ice at a distance of $\sim 40 \mathrm{~cm}$ from the drilled hole

Chlorophyll $a$ and algae. For chl a determinations, $100 \mathrm{ml}$ samples were filtered gently $(\leq 100 \mathrm{~mm} \mathrm{Hg})$ onto $25 \mathrm{~mm}$ Whatman GF/F filters. The chl $a$ on the filters was extracted in the dark at room temperature in $95 \%$ ethanol for $24 \mathrm{~h}$ without grinding. Fluorescence was measured in a Perkin Elmer fluorometer (LS 30) and chl a was calculated according to HELCOM (1988). The average coefficient of variation based on triplicates for chl a measurements was $12 \%$. Samples for algal species analysis were fixed with Lugol's solution at a final concentration of $2 \%$, concentrated in a sedimentation chamber and studied in an inverted microscope at 200 to $400 \times$ magnification.

Primary production. Primary production was measured by the ${ }^{14} \mathrm{C}$ technique (Parsons et al. 1984). Triplicate light and dark samples $(5 \mathrm{ml})$, consisting of brine from the top, middle and bottom of the ice cores, were poured into polycarbonate tubes (Nalgene). Brine samples, rather than whole ice, were used for production measurements since sea ice microbial communities live within the brine. An inocculum of $0.64 \mu \mathrm{Ci}$ of carrierfree sodium $\left({ }^{14} \mathrm{C}\right)$ bicarbonate $\left(0.1 \mathrm{mCi} \mathrm{mmol}^{-1}\right)$ was added to the samples, and they were incubated for 3 to $4 \mathrm{~h}$ around noon in the ice at the sampling station. To create in situ light and temperature conditions, samples were incubated in ice holes drilled to sampling depths (centre of the top, middle and bottom sections), and covered with ice and snow. After incubation, $\mathrm{HCl}$ was added to a final concentration of $0.4 \mathrm{M}$ to remove excess ${ }^{14} \mathrm{C}$-bicarbonate. The samples were bubbled with air for $30 \mathrm{~min}$ and left overnight to free the samples of residual ${ }^{14} \mathrm{C}$-bicarbonate. Scintillation cocktail (Optiphase 'Highsafe' III) was added, and the samples were counted in a scintillation counter (Beckman LS1801). The daily assimilation values were calculated by multiplying the measured primary production rates with the ratio between total daily insolation and insolation during the incubation period. The primary production in the ice core was calculated by multiplying the production in the brine with a chl a factor [(chl a ice)/(chl a brine)], since during drainage only a fraction of the brine and organisms contained within it was recovered. The average coefficient of variation based on triplicates for primary production measurements was $11 \%$. Pelagic primary production measurements were performed as described in Andersson et al. (1994).

Heterotrophic bacterial and flagellate biomass. Formaldehyde was added to ice brine samples, samples from wholly melted ice cores, and water column samples (final concentration $1.5 \%$ ). For the determination of bacterial biomass a 2 to $15 \mathrm{ml}$ sample was filtered onto black $0.2 \mu \mathrm{m}$ polycarbonate filters, stained with acridine orange, mounted in paraffin oil, and examined by epifluorescence microscopy (Hobbie et al. 1977). Estimates of bacterial cell volumes were acquired by image analysis (Blackburn et al. 1998).

Samples for counting heterotrophic flagellates from the ice $(5$ to $20 \mathrm{ml})$, were stained with acridine orange at a final concentration of $2.4 \mathrm{ppm}$ and filtered onto black $0.8 \mu \mathrm{m}$ polycarbonate filters. By using this weak staining, the heterotrophic microorganisms could be distinguished from the autotrophic ones by the $a b$ sence of autofluorescence (Andersen \& Sorensen 1986). At least 50, but in most cases 100 , small flagellate cells $(<10 \mu \mathrm{m})$ per slide were counted at $1250 \times$ magnification. Between 10 and 100 medium-sized flagellate cells $(\geq 10 \mu \mathrm{m})$ per slide were counted at $250 x$ magnification. The sizes of all cells were measured under the microscope using a calibrated ocular micrometer. The cell volumes were calculated assuming simple geometric shapes approximating those of the organisms. Small- and medium-sized heterotrophic 
flagellates from the water column were fixed with acid Lugol's solution at a final concentration of $2 \%$, and 10 to $50 \mathrm{ml}$ of the sample was concentrated in a sedimentation chamber. One chamber diameter was scanned in an inverted microscope at $400 \times$ magnification using phase contrast, and heterotrophic flagellates were identified by morphology and coloration. The cell carbon content of bacteria and flagellates was calculated from cell volume: pgC cell $^{-1}=0.125 \times$ cell volume $\left(\mu m^{3}\right)$ (Pelegrí et al. 1999).

Bacterial production. Bacterial production was measured by the tritiated ${ }^{3} \mathrm{H}$-thymidine incorporation method (Fuhrman \& Azam 1982), modified by centrifugation of the samples. Triplicate brine samples and controls were incubated in darkness at in situ temperatures. The saturation level of ${ }^{3} \mathrm{H}$-thymidine (specific activity, $82 \mathrm{Ci} \mathrm{mmol}^{-1}$ ) uptake was measured at the beginning of the sampling season (19 January 1996). ${ }^{3} \mathrm{H}$-thymidine was added to brine samples in the range of 5.8 to $47 \mathrm{nM}$, and the saturation level was found to be $23.3 \mathrm{nM}$. This concentration was added to bacterial production samples over the whole sampling period, assuming a constant saturation level. The pelagic samples were treated as described above, but with the addition of $25 \mathrm{nM}{ }^{3} \mathrm{H}$-thymidine. Bacterial production was calculated using the empirical conversion factor $1.5 \times 10^{18}$ cells $\mathrm{mol}^{-1}{ }^{3} \mathrm{H}$-thymidine incorporated, which has been estimated for the northern Baltic Sea (Wikner \& Hagström in press). The bacterial production in the ice core was calculated by multiplying the production in the brine with a bacterial biomass factor [(ice bacterial biomass)/(brine bacterial biomass)] The average coefficient of variation based on triplicates for measured bacterial production rates was $14 \%$

\section{RESULTS}

The studied area was covered with 35 to $70 \mathrm{~cm}$ of sea ice from January to April and from the end of January to the middle of April there was 6 to $13 \mathrm{~cm}$ snow on the ice (Fig. 2a). The average daily air temperature fluctuated between -20 and $+4^{\circ} \mathrm{C}$ during the study period (Fig. 2b).
February was the coldest month, with temperatures frequently dropping below $-15^{\circ} \mathrm{C}$. After 12 April, air temperatures were generally $>0^{\circ} \mathrm{C}$. The water temperature under the ice $(0 \mathrm{~m})$ was -0.11 to $-0.23^{\circ} \mathrm{C}$ from January through March, which is close to the freezing temperature of brackish water with $4 \%$ salinity $\left(-0.24^{\circ} \mathrm{C}\right.$; Fig. 2b). After 12 April the water tempera-

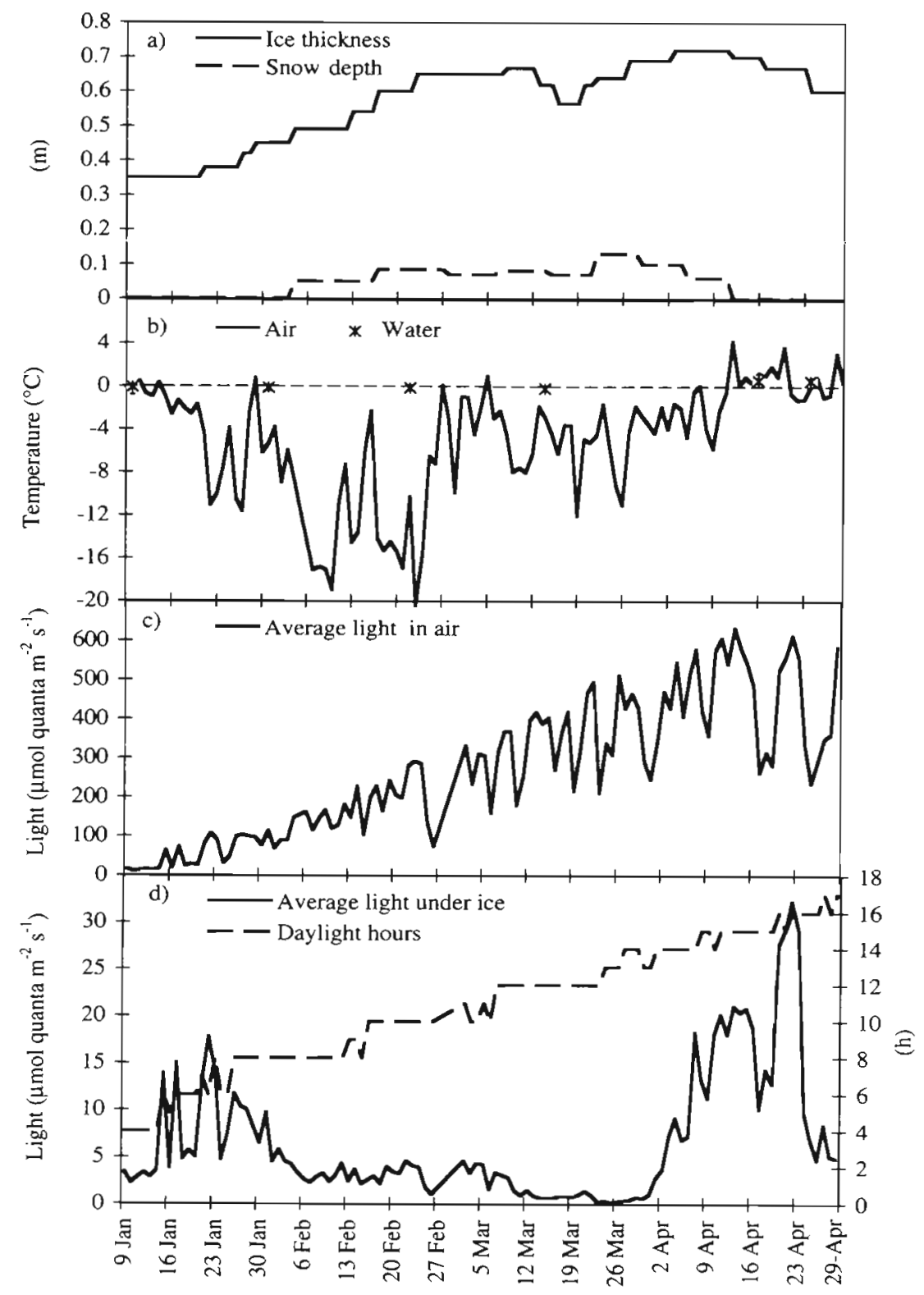

Fig. 2. (a) Thickness of the ice and the snow depth at the sampling site during the ice covered season 1996. (b) Temperature in the air and the water under the ice $(0 \mathrm{~m})$, and $(\mathrm{c})$ the average incident irradiance during the daylight hours. Daylight hours were defined as the hours where the irradiance was $>7 \mu \mathrm{mol}$ quanta $\mathrm{m}^{-2} \mathrm{~s}^{-1}$ (d) Light under the ice $\left(I_{2}\right)$ was calculated according to Beers law: $I_{z}=I_{0} \mathrm{e}^{-k z}$ where $I_{0}$ is the intensity at the surface and $k$ is the extinction coefficient. $I_{0}$ was measured hourly during the sampling period; $k$ was calculated from measured light intensities under the ice 
ture increased to $>0.5^{\circ} \mathrm{C}$. The average incident irradiance during daylight hours increased from $\sim 20 \mu \mathrm{mol}$ quanta $\mathrm{m}^{-2} \mathrm{~s}^{-1}$ in the beginning of January to $\sim 600 \mu \mathrm{mol}$ quanta $\mathrm{m}^{-2} \mathrm{~s}^{-1}$ at the end of April (Fig. 2c). The number of daylight hours increased steadily through the sampling period from 4 to $17 \mathrm{~h}$ (Fig. 2d). The average light intensity under the ice varied between 2 and $18 \mu \mathrm{mol}$ quanta $\mathrm{m}^{-2} \mathrm{~s}^{-1}$ in January. Due to increasing ice thickness and the development of a snow cover, light under the ice dropped to $0.2-6 \mu \mathrm{mol}$ quanta $\mathrm{m}^{-2} \mathrm{~s}^{-1}$ in February to March. In April the snow disappeared and the average light under the ice increased up to $30 \mu \mathrm{mol}$ quanta $\mathrm{m}^{-2} \mathrm{~s}^{-1}$ for $16 \mathrm{~h} \mathrm{~d}^{-1}$.

The water column salinity was relatively stable during the sampling period $(\sim 4 \%)$, while the brine and the ice salinity varied between $2-12$ and $0.2-1.6 \%$, respectively (Fig. 3). The ice and the brine salinity generally decreased during the study, due to gradual desalination. Desalination of sea ice is commonly caused by gravity drainage and flushing by surface melt-water (Maykut 1985). Between 30 January to 20 February and 2 to 9 April brine salinity increased, indicating that the brine had been freezing. The inorganic

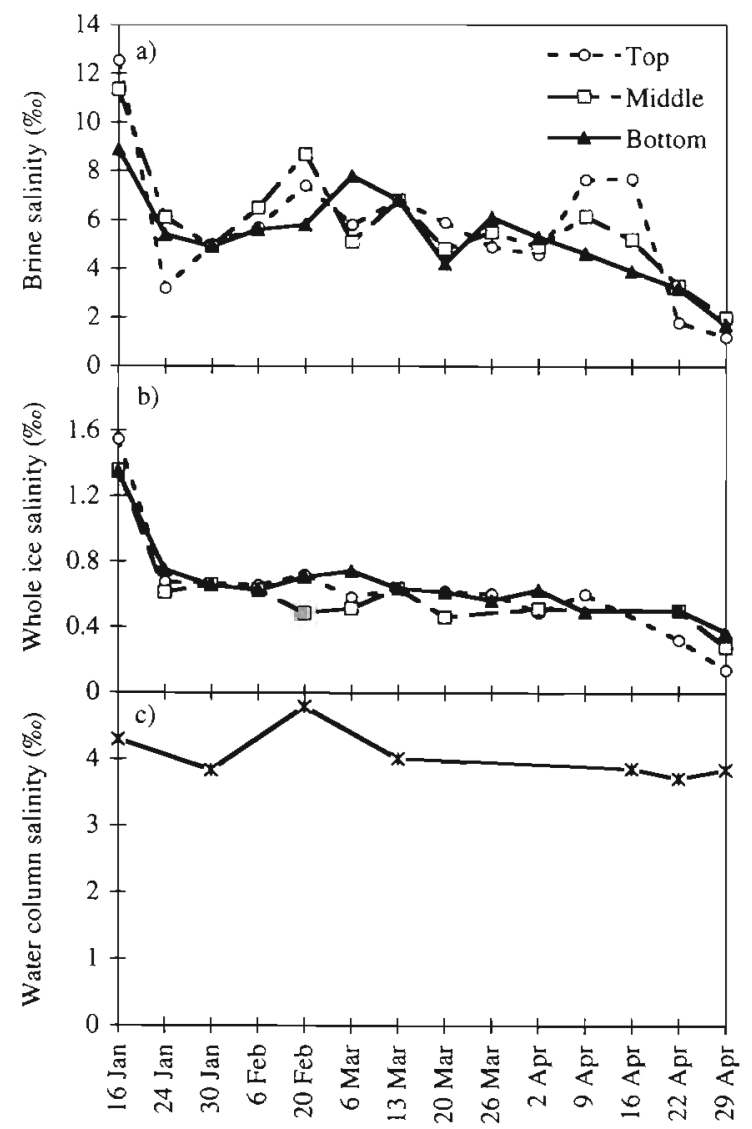

Fig. 3. Salinity of the (a) brine, (b) ice and (c) the water under the ice at $2 \mathrm{~m}$ depth nutrient concentrations in the brine were normalized to seawater salinity $(4.3 \%)$, to correct for dilution or concentration during melting or freezing. Normalized concentrations of phosphate, nitrate + nitrite and ammonium in the brine were generally higher than those in the water column (Fig. 4a,b,c). However on 16 April, the nutrient concentrations in brine from the bottom and middle of the ice reached a minimum and were similar to those in the water column. Silicate concentrations were similar in the brine and in the water column during the whole sampling period (Fig. 4d).

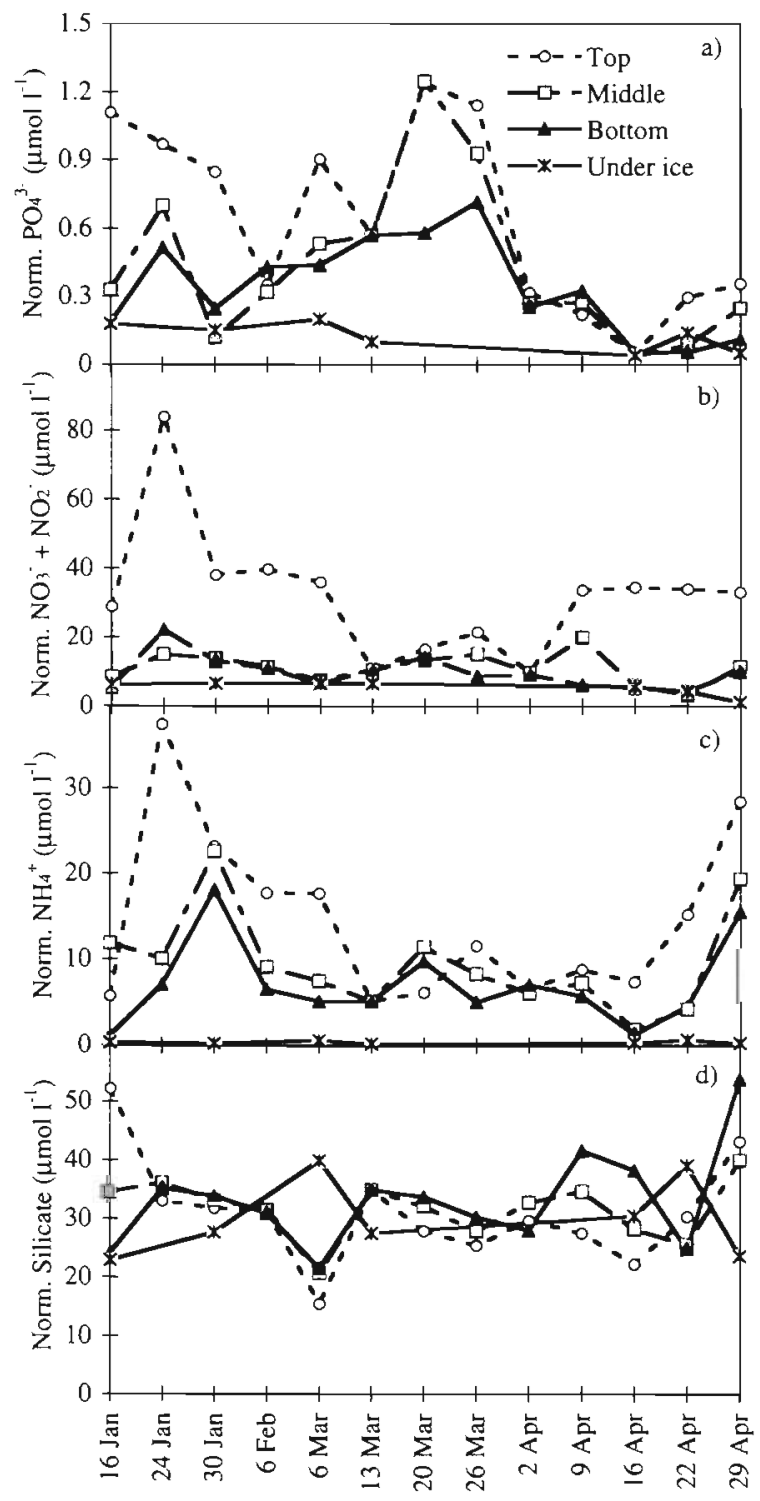

Fig. 4. Concentrations of (a) dissolved inorganic phosphate (DIP), (b) nitrite + nitrate, (c) ammonium and (d) silicate in brine from the top, middle and bottom of the ice and in the water under the ice $(2 \mathrm{~m})$. The brine nutrient concentrations are normalized to seawater salinity $(4.3 \%)$ 
Production rates of the ice were calculated from the production in the brine multiplied by ice biomass/brine biomass, assuming that algal and bacterial specific activities were the same in the ice remaining after brine removal. If part of the microbial biomass was frozen into the ice or selectively retained within the ice during drainage due to large cell size, the collected microorganisms would not be representative of the whole ice microbial community. The total brine volume in the ice was calculated from salinity and temperature of ice (Maykut 1985), and compared to the amount of collected brine (Table 1). The proportion of the bacterial biomass drained out of the ice was on average $10 \%$ of the total bacterial biomass, which was close to the amount of brine drained out of the ice $(11 \%)$. This indicates that bacteria were not frozen into the ice matrix,

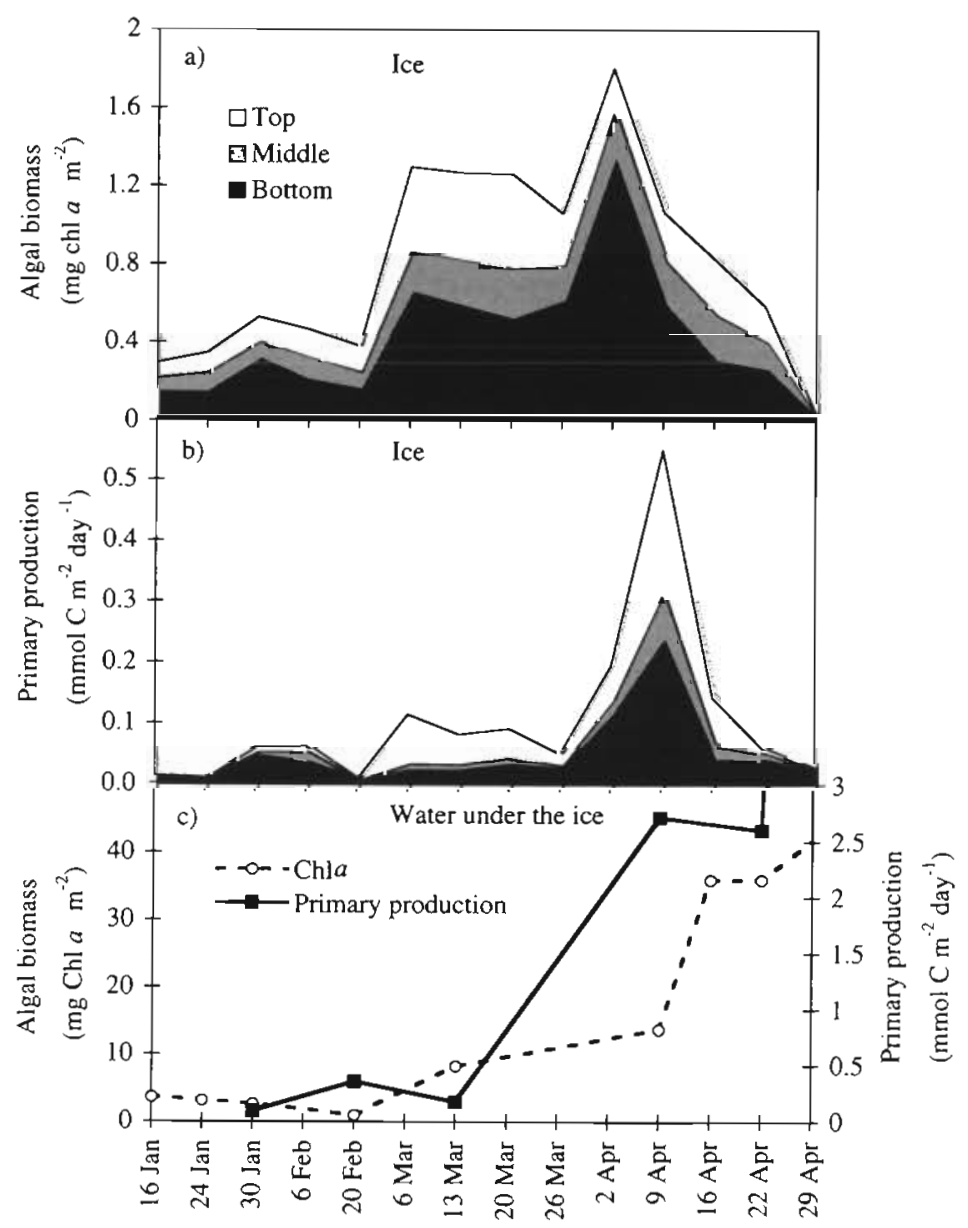

Fig. 5. (a) Chlorophyll $a$, and (b) primary production rates in the sea ice, and (c) in the water column, integrated from 0 to $20 \mathrm{~m}$ depth and were readily drained out of the ice. However, only $\sim 5 \%$ of the ice algal biomass was collected during brine drainage, as opposed to the $11 \%$ of brine collected. This indicates that half of the ice algae were either frozen into the ice matrix, or 'stuck' in the ice pores during drainage (large cells that were unable to pass through thin brine channels). The method we used to calculate whole ice primary and bacterial production rates might thus have overestimated ice primary production rates, while bacterial production rates were closer to the true values.

Both chl a concentration in the ice and ice algal primary production per area were relatively stable and low from January to February, while both increased from 20 February to 6 March (Fig. 5a,b). In March, chl a concentration and primary production were again stable at a somewhat higher level. Concurrent with increasing light intensities and day lengths, an ice algal bloom occurred in the beginning of April, as indicated by peaks in the chl a concentrations and primary production. After the ice algal bloom, chl a concentration and primary production decreased rapidly. The phytoplankton spring bloom was observed after the ice break-up, but had already started during April under the ice (Fig. 5c).

The ice algal community was mainly composed of diatoms, but the autotrophic dinoflagellate Peridiniella catenata (Levander) Balech and the mixotrophic microflagellate Dinobryon faculiferum (Wille'n) Wille'n (Chrysophyceae) were relatively common. Small unidentified autotrophic flagellates were also frequently observed. Navicula pelagica Cleve was found throughout the sampling season and dominated during the ice algal bloom. Nitzschia frigida Grunow., Melosira arctica (Ehrenberg) Dickie, Chaetoceros wighamii Brightwell and Navicula vanhoeffenii Gran were also commonly found. 
The bacterial abundance varied from $\sim 7 \times 10^{4}$ to $2.7 \times 10^{5}$ cells $\mathrm{ml}^{-1}$ in the ice, $4.2 \times 10^{5}$ to $2.3 \times 10^{6}$ cells ml ${ }^{-1}$ in the brine and between $7.5 \times 10^{5}$ and $1.3 \times 10^{6}$ cells $\mathrm{ml}^{-1}$ in the water column (data not shown). The ice bacterial biomass remained relatively stable during the whole sampling period (Fig. 6a). The bacterial production in the ice was relatively high at the beginning of January, while it was low during February and March (Fig. 6b). In April the bacterial production rate increased rapidly, following the ice algal bloom. The pelagic bacterial biomass was stable throughout the sampling season, while the pelagic bacterial production was slowly increasing (Fig. 6c). The bacterial production per biomass varied between 0.006 and $0.05 \mathrm{~d}^{-1}$ from January to March, and after that it increased rapidly up to $-0.25 \mathrm{~d}^{-1}$ (16 to 22 April) and finally to $0.38 \mathrm{~d}^{-1}$ (29 April). In the pelagic

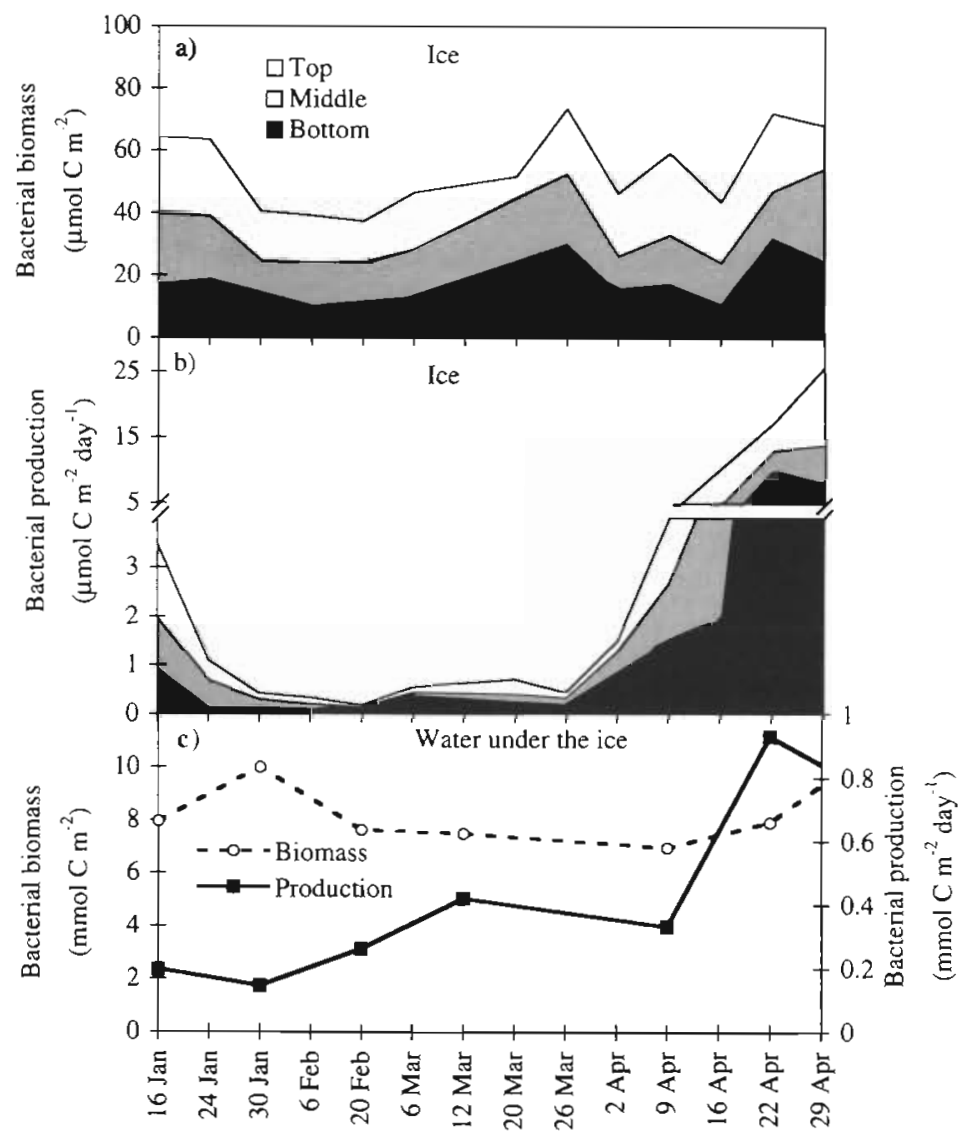

Fig. 6. $(\mathrm{a}, \mathrm{b})$ Bacterial biomass and production (calculated from ${ }^{3} \mathrm{H}$-thymidine uptake rates) in the ice. (c) Bacterial biomass and production in the water column, integrated from 0 to $20 \mathrm{~m}$ depth system, bacterial production per biomass varied between 0.01 and $0.12 \mathrm{~d}^{-1}$ during the whole sampling period. Thus, the specific growth rates of ice bacteria were higher than bacterial growth rates in the water column during and after the ice algal bloom.

Spatial variations of primary and bacterial production, chl $a$ and bacterial biomass in ice were determined during transect samplings (13 and 26 March). The transects consisted of 6 stations, from the nearshore, high frequency sampling station to a station situated $10 \mathrm{~km}$ offshore (Table 2). The coefficients of variation (CV) of the spatial variation for chl $a$ and primary production were high (31 to 44 and 35 to $57 \%$, respectively) relative to the coefficients of variation of triplicate samples within ice cores (12 and $11 \%$ respectively). However, the temporal variations of $\mathrm{chl} a$ and primary production varied by a factor of 6 and 65 respectively between minimum and maximum values, while areal chl a concentrations and primary production rates varied by a factor of 3 to 4 and 2.4 to 6 respectively. This indicates that the temporal variations of chl a and primary production were higher than spatial variations in the studied area. The transect sampling on 26 March indicated high spatial variation of bacterial production rates by the high CV for production rates measured during the transect $(73 \%)$ relative to the average $\mathrm{CV}$ of triplicate samples within ice cores $(14 \%)$. However, temporal variations between minimum and maximum values of the measured bacterial biomass and production rates varied by a factor of 6 and 65 , respectively, while areal rates varied by a factor of 3 and 6 , respectively. This indicates that the temporal variations of bacterial biomass and production were higher than spatial variations in the studied area. 
The biomasses of small- and medium-sized heterotrophic flagellates were relatively low until the beginning of April (Fig. 7a,b). On 9 April, during the peak in primary production, the biomass of both small- and medium-sized flagellates started to increase. Both size classes of flagellates reached their peaks on 16 April after the primary production maximum. The heterotrophic flagellates in the water column under the ice increased simultaneously with the flagellates in the ice (Fig. $7 \mathrm{c}$ ). The abundance of small- and medium-sized heterotrophic flagellates in the ice were between $8.5 \times 10^{1}$ to $5.9 \times 10^{3}$ and 3 to 16 cells $\mathrm{ml}^{-1}$ respectively (data not shown). The heterotrophic flagellate component was dominated by unidentified small heterotrophic flagellates. Medium-sized heterotrophic flagellates were

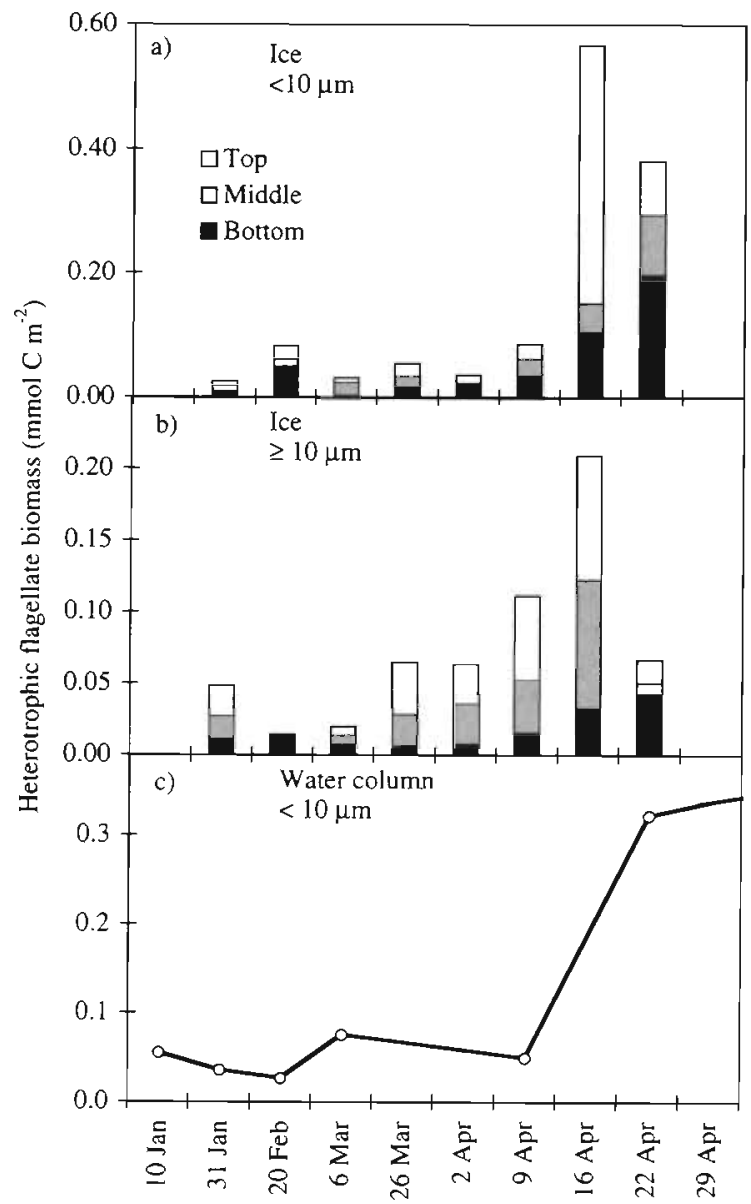

Fig. 7. Biomass of (a) small $(<10 \mu \mathrm{m})$ heterotrophic flagellates and (b) medium-sized ( $\geq 10 \mu \mathrm{m}$ ) heterotrophic flagellates in the ice, and (c) in the water under the ice integrated from 0 to $20 \mathrm{~m}$
Table 3. Monthly ice algal and bacterial production during the ice covered season 1996 (data range within parentheses). The contribution of ice production to the total production (pelagic + ice) in the studied sea area is also shown

\begin{tabular}{|lccc|}
\hline $\begin{array}{c}\text { Ice primary } \\
\text { production } \\
\left(\mathrm{mmol} \mathrm{C} \mathrm{m}^{-2}\right)\end{array}$ & $\begin{array}{c}\text { Ice bacterial } \\
\text { production } \\
\left(\mathrm{mmol} \mathrm{C} \mathrm{m}^{-2}\right)\end{array}$ & $\begin{array}{c}\text { Bacterial production } \\
\text { in of primary } \\
\text { production }\end{array}$ \\
\hline January & 0.51 & 0.06 & $11.9(0.7-24.8)$ \\
February & 1.35 & 0.01 & $0.7(0.5-3.0)$ \\
March & 2.40 & 0.02 & $0.7(0.5-0.9)$ \\
April & 5.37 & 0.33 & $6.2(0.7-106)$ \\
Sum & 9.54 & 0.42 & 4.4 \\
Ice production compared to total production (ice + water column) & \\
Ice-covered season & 10.1 & $(\%)$ & \\
Annual & 0.38 & 0.18 & \\
\hline
\end{tabular}

composed of dinoflagellates, and unidentified flagellates. The biomass concentrations of algae and heterotrophic flagellates were generally higher in ice than in the water column, whereas the biomass of bacteria was lower in the ice than in the water column (data not shown). Calculated on an areal basis, the bacterial, algal and flagellate biomasses were considerably lower in the ice than in the water column (Figs. 5, 6 \& 7).

In order to estimate the significance of ice production in the studied area, the production values in the ice and in the water column were compared during the ice-covered season and over the whole year (Table 3). The ice primary production accounted for $10 \%$ of the total production during the ice-covered season, while bacterial production in the ice accounted for $0.2 \%$ of the total bacterial production over the same period. On an annual basis, ice primary and bacterial production were $<1$ and $<0.1 \%$ respectively of the total production.

\section{DISCUSSION}

The maximum ice algal biomass was approximately the same as that observed in a study performed at the same location during 1994 (1.5 $\mathrm{mg} \mathrm{chl} \mathrm{a} \mathrm{m} \mathrm{m}^{-2}$. Haecky et al. 1998), but lower than that found during winter 1990 (10 $\mathrm{mg}$ chl a m $\mathrm{m}^{-2}$, Norrman \& Andersson 1994). The main difference between the study in 1990, with high ice algal biomass, and the 2 other studies was the nutrient concentration in the water column. In 1990, phosphate in the water column was $1.6 \mu \mathrm{M}$ at the beginning of the ice-covered season, but in 1994 and 1996 the concentration was only 0.12 and $0.18 \mu \mathrm{M}$ respectively (Fig. 4; Andersson et al. 1994, Haecky et al. 1998). The potential ice algal biomass in $70 \mathrm{~cm}$ sea ice from the given phosphate concentration would be $40,3.0$ and $4.5 \mathrm{mg} \mathrm{chl} \mathrm{a} \mathrm{m} \mathrm{m}^{-2}$ in 1990, 1994 and 1996, respectively 
(calculated by using the Redfield molar C:P ratio of 106, and the conversion factor $3 \mathrm{~mol} \mathrm{C} \mathrm{g}^{-1} \mathrm{chl} a$; Redfield et al. 1963, Haecky et al. 1998). The actual ice algal biomass concentrations were less than half of the potential concentrations, where the difference was most likely caused by brine drainage and predation. From the 3 studies in northern Baltic Sea ice, it can be concluded that the ice algal biomass accumulation depends on the amount of nutrients (particularly P) trapped in the ice during the ice algal bloom period. The ice algal biomass in the northern Baltic Sea was low compared to those found in, for example, Arctic and Antarctic sea ice (Legendre et al. 1992, Kirst \& Wiencke 1995). Also, nutrient concentrations measured in the water column in this study were low compared to winter nutrient concentrations in the Atlantic and Pacific Oceans (Sakshaug 1989), resulting in a lower potential ice microbial biomass.

Light, rather than nutrients, limited ice algal growth during the first 3 mo of the investigation, since the phosphate concentration in the brine, before the ice algal bloom, was higher than $k_{\mathrm{s}}$ measured for mixed natural phytoplankton populations average $k_{\mathrm{s}}=0.27 \mu \mathrm{M}$, range $=0.05$ to $0.5 \mu \mathrm{M}$; Cembella et al. 1984). The marked increase of primary production in response to increasing light availability, in the beginning of April, also showed that ice algae were light limited (Figs. 2d \& 5b). Decreasing phosphate concentrations between 9 and 16 April might have been the cause of the crash of the ice algal bloom. Mortality of polar diatoms can be induced by nutrient exhaustion in combination with high $\mathrm{pH}$, oxygen oversaturation, and low $\mathrm{CO}_{2}$ concentration, which are conditions that are regularly attained during advanced stages of ice algal blooms (Günther et al. 1999).

Good correlation between bacterial and primary production was found from the end of January to 9 April $\left(r^{2}=0.91\right)$. Similar trends have been observed in sea ice from the western Baltic Sea and Antarctica, where a strong linkage between primary and bacterial production was observed (Kottmeier et al. 1987, Mock et al. 1997). During the spring bloom, bacterial production constituted 3 to $5 \%$ of the ice algal primary production in Resolute Passage, High Arctic (Smith \& Clement 1990). However, bacterial production exceeded primary production in sea ice studied during autumn and

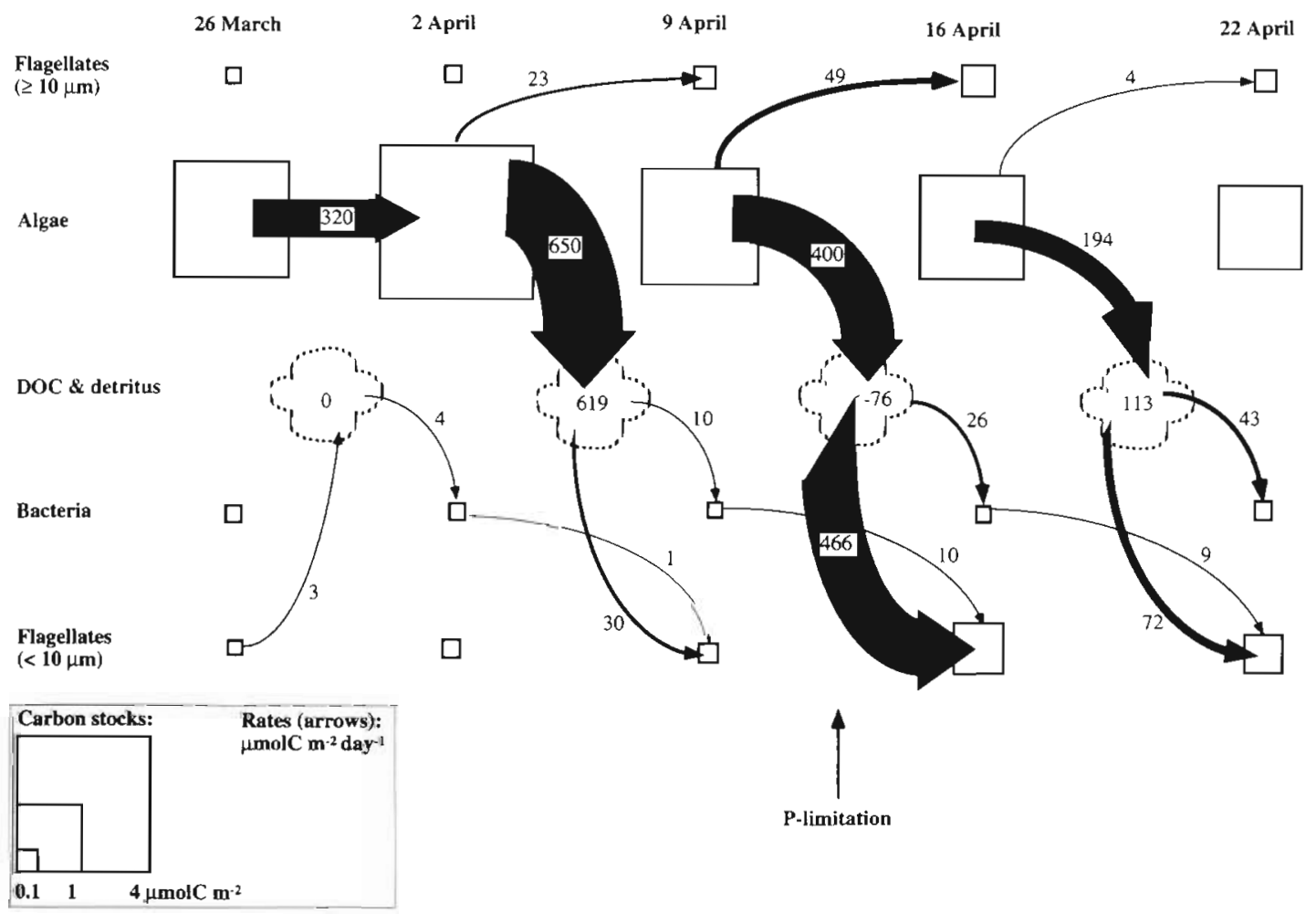

Fig. 8. Carbon budget of microbial processes in sea ice during and after the ice algal bloom (26 March and 22 April, 1996). Carbon stocks of algae, bacteria and heterotrophic flagellates are shown in boxes and production rates are shown by arrows. Algal carbon was calculated from $\mathrm{chl} \mathrm{a}\left(3 \mathrm{~mol} \mathrm{C} \mathrm{g}^{-1} \mathrm{chl} \mathrm{a}\right)$, and carbon flow rates from production rates and changes in carbon stocks. The growth efficiency of bacteria and heterotrophic flagellates was assumed to be $40 \%$. Medium-sized heterotrophic flagellates $(\geq 10 \mu \mathrm{m})$ were assumed to graze on algae, and small heterotrophic flagellates $(<10 \mu \mathrm{m})$ on bacteria. In cases where the carbon demand of small heterotrophic flagellates exceeded the bacterial carbon production, ingestion of DOC and detritus is suggested 
winter (Kottmeier et al. 1987, Rivkin et al. 1989). In the present study, total bacterial production during the icecovered season equaled $4 \%$ of the ice primary production, which was similar to the spring situation described above (Table 3). During April part of the bacterial production was either grazed or lost from the ice, since the bacterial production increased rapidly, while bacterial biomass remained relatively stable (Fig. 6a,b). A similar situation was observed in ice from Forbisher Bay (Canadian Subarctic), where the increase of bacterial standing stock was low compared to bacterial cell production (Bunch \& Harland 1990).

A budget of the known carbon pools and flows during and after the ice algal bloom is outlined in Fig. 8. Following the ice algal bloom, the algal biomass decreased, while algal growth increased rapidly. The resulting loss of ice algal biomass could only partly be accounted for by rapidly increasing heterotrophic flagellate biomasses (Fig. $7 \mathrm{a}, \mathrm{b}$ ). The carbon demand of medium-sized heterotrophic flagellates between 2 to 29 April accounted for 2 to $11 \%$ of the algal loss rate, calculated from biomass accumulation and assuming a growth efficiency of $40 \%$ (Table 4; Sanders et al. 1992). The carbon demand of medium-sized heterotrophic flagellates was similar to findings from the Canadian Arctic, where microprotozoan carbon consumption was estimated to be 1 to $8 \%$ of the net biomass loss from the ice algal population (Sime-Ngando et al. 1997). The specific growth rates of the microprotozoan populations in sea ice from the Canadian Arctic were also similar to the growth rates estimated in the present study (Table 4 ). The remaining loss of algal biomass, not consumed by flagellates or bacteria, was considered to accumulate in a detrital pool, which potentially might have resulted in high concentrations of dissolved organic matter (DOM). In bottom ice from the Canadian Arctic and northern Japan, ice

Table 4. Growth rate and net production rate of heterotrophic flagellates, calculated from biomass changes during and after the ice algal bloom

\begin{tabular}{|c|c|c|c|c|c|}
\hline & & \multicolumn{2}{|c|}{$\begin{array}{c}\mu^{\mathrm{d}} \\
\left(\mathrm{d}^{-1}\right)\end{array}$} & \multicolumn{2}{|c|}{$\begin{array}{l}\text { Net production rate } \\
\left(\mu \mathrm{mol} \mathrm{C} \mathrm{m}^{-2} \mathrm{~d}^{-1}\right)\end{array}$} \\
\hline & & 2-9 Apr & $9-16 \mathrm{Apr}$ & $9 \mathrm{Apr}$ & $16 \mathrm{Apr}$ \\
\hline Small & Top & 0.08 & 0.41 & 1.9 & 169.7 \\
\hline heterotrotrophic & Middle & 0.28 & 0.07 & 7.9 & 3.4 \\
\hline flagellates & Bottom & 0.09 & 0.17 & 2.8 & 17.1 \\
\hline$(<10 \mu \mathrm{m})$ & Sum & & & 12.5 & 190.3 \\
\hline Medium-sized & Top & 0.10 & 0.06 & 6.0 & 5.0 \\
\hline heterotrotrophic & Middle & 0.04 & 0.12 & 1.6 & 11.0 \\
\hline flagellates & Bottom & 0.10 & 0.11 & 1.5 & 3.7 \\
\hline$(\geq 10 \mu \mathrm{m})$ & Sum & & & 9.0 & 19.8 \\
\hline \multicolumn{6}{|c|}{$\begin{array}{l}{ }^{\circ} \text { Growth rate } \mu\left(\mathrm{d}^{-1}\right)=\left(\ln N_{t}-\ln N_{0}\right) / t . N_{t} \text { was flagellate biomass at time } t \text {, } \\
N_{0} \text { at time } 0 \\
\text { b Net production rate }\left(\mu \mathrm{mol} \mathrm{C} \mathrm{m}^{-2} \mathrm{~d}^{-1}\right)=\mu\left(\mathrm{d}^{-1}\right) \times \text { flagellate-C }\left(\mu \mathrm{mol} \mathrm{C} \mathrm{m}^{-2}\right)\end{array}$} \\
\hline
\end{tabular}

algae were the major source of dissolved organic carbon (DOC), and concentrations up to $480 \mathrm{mmol} \mathrm{C} \mathrm{^{-1 }}$ were found (Smith et al. 1997). Metazoan grazing was most likely responsible for part of the ice algal biomass lost from the ice after the ice algal bloom, since these have been found in relatively high concentrations in the lowermost section of sea ice from the northern Baltic Sea (Synchaeta baltica, Norrman \& Andersson 1994).

Bacterial production alone was insufficient to sustain the observed growth of small heterotrophic flagellates just after the ice algal bloom, since the carbon demand was more than 1 order of magnitude higher than the bacterial production rate (Fig. 8). Moreover, the estimated carbon demands of flagellates are minimum estimates, since they are based on net changes in numbers and losses of flagellates were not accounted for in the present budget. This indicates that the heterotrophic flagellates used carbon sources other than bacteria for growth (e.g. grazing on small primary producers, viruses or direct uptake of DOM). In the Canadian Arctic, the bacterial grazing rate seemed sufficient to meet heterotrophic flagellate carbon demand before the ice algal bloom, but became inadequate after the ice algal bloom (Laurion et al. 1995). The authors suggested that the consumption of small algae and direct ingestion of DOM became more important after the ice algal bloom. Thus, the heterotrophic flagellates in sea ice seem to be able to utilize more diverse food sources than flagellates from the pelagic system.

The contribution of ice algal production to the total primary production during the ice-covered season was $10 \%$ (Table 3). In Arctic regions, where the ice cover was 55 to $90 \%$ of the surface area, the ice algal contributions to total primary production rates were close to those found in the present study $(2$ to $5 \%$, Gosselin et al. 1997). A significantly higher contribution of the ice algal production to the total production was found in the $>90 \%$ ice-covered central Arctic Ocean, where the ice algal contribution was $57 \%$. In the present study, the contribution of the total ice algal production to the annual water column production was $0.4 \%$, which was considerably lower than values reported from the Arctic first year ice ( 3 to $25 \%$, Legendre et al. 1992). The main reasons for higher ice algal production in annual sea ice from the Arctic Ocean are the longer icecovered season compared to that of the northern Baltic Sea, and higher nutrient concentration in the water during ice formation, resulting in higher potential ice algal biomass (see above). 
Highly productive bottom ice algal communities have not been observed in the northern Baltic Sea, but are assumed to occur under much of the Arctic Sea ice, thus increasing the ice algal production. However, maximal ice algal biomasses in the northern Baltic Sea have been observed to vary over 1 order of magnitude (see above). In addition to that, the annual pelagic primary production rates vary by a factor of 6 among different years in this sea area (1984 to $1996: 1$ to $5.6 \mathrm{~mol} \mathrm{C} \mathrm{m}^{-2} \mathrm{yr}^{-1}$ (Nordström \& Wikner 1996). This suggests that the contribution of the ice algal production to the total annual production might vary at least 1 order of magnitude.

The contribution of the ice bacterial production to the total production was $<<1 \%$ both on an annual basis and during the ice-covered season. In Antarctic Sea ice (McMurdo Sound), the ice bacterial production accounted for 3 to $5 \%$ of the total bacterial production in platelet ice and for 1 to $2 \%$ in congelation ice during late winter and early spring. The reason for the low ice bacterial production in this study was presumably grazing of bacteria as indicated by the relatively abundant presence of small heterotrophic flagellates.

It seems that the microbial community in sea ice from the northern Baltic Sea developed through 3 phases: from January to March a light-limited, low productive winter community developed. During the first half of April a spring bloom community with rapidly increasing primary productivity developed, followed by a post bloom community, where heterotrophic processes dominated. Ice bacteria seemed to play only a minor role in the carbon turnover, while heterotrophic flagellates, particularly after the ice algal bloom, played a major role. However, to acquire a deeper understanding of the ecological processes within the sea ice of the Gulf of Bothnia, more work is needed on the production and turnover of the organic carbon pool as well as the nutrition of heterotrophic flagellates

Acknowledgements. This work was supported by grants from the Swedish National Sciences Research Council (B-AA/BU 06554-304), and from EU (BASYS MAS3-CT96-0058). We thank Birgitta Karlsson, Kristina Samuelsson and Jonas Wester for help with the field work, and Erik Lundberg and Carl-Henrik Stangenberg for chemical analysis. Furthermore we would like to thank Sheila and Henry Blackburn for linguistic corrections, and Tom Fenchel for help with the microscopic work. The laboratory facilities and the use of data from the pelagic monitoring program at Umea Marine Sciences Center are gratefully acknowledged.

\section{LITERATURE CITED}

Andersen $\mathrm{P}$, Sørensen $\mathrm{H}$ (1986) Population dynamics and trophic coupling in pelagic microorganisms in eutrophic coastal waters. Mar Ecol Prog Ser 33:99-109

Andersson A, Haecky P, Hagström $\AA$ (1994) Effect of temperature and light on the growth of micro-, nano- and pico- plankton: impact on algal succession. Mar Biol 120: 511-520 Blackburn N, Hagström $\AA$, Wikner J, Hansson RC, Bjørnsen PK (1998) Rapid determination of bacterial abundance, biovolume, morphology, and growth by neural networkbased image analysis. Appl Environ Microbiol 64: 3246-3255

Bunch JN, Harland RC (1990) Bacterial production in the bottom surface of sea ice in the Canadian subarctic. Can J Fish Aquat Sci 47:1986-1995

Cembella A, Antia N, Harrison P (1984) The utilization of inorganic and organic phosphorus compounds as nutrients by eucaryotic microalgae: a mulitdisciplinary perspective. CRC Crit Rev Microbiol 10:317-391

Cota GF, Legendre L, Gosselin M, Ingram RG (1991) Ecology of bottom ice algae: 1. Environmental controls and variability. J Mar Syst 2:257-277

Dieckmann GS, Lange MA, Ackley SF, Jennings JC Jr (1991) The nutrient status in sea ice of the Weddell Sea during winter: effects of sea ice texture and algae. Polar Biol 11: $449-456$

Fuhrman J, Azam F (1982) Thymidine incorporation as a measure of heterotrophic bacterioplankton production in marine surface waters: evaluation and field results. Mar Biol 66:109-120

Garrison DL (1991) Antarctic sea ice biota. Am Zool 31:17-33

Gleitz G, Rutgers van der Loeff $M$, Thomas DN, Dieckman GS, Millero FJ (1995) Comparison of summer and winter inorganic carbon, oxygen and nutrient concentrations in the Arctic sea ice brine. Mar Chem 51:81-91.

Gosselin M, Legendre L, Therriault JC, Demers S (1990) Light and nutrient limitation of sea-ice microalgae (Hudson Bay, Canadian Arcticl. J Phycol 26:220-232

Gosselin M, Levasseur M, Wheeler P, Horner R, Boot B (1997) New measurements of phytoplankton and ice algal production in the Arctic Ocean. Deep-Sea Res 44:1623-1644

Grasshoff K, Ehrhardt M, Kremling K (1983) Methods of seawater analysis, 2nd revised and extended version. Verlag Chemie, Weinheim

Günther S, Gleitz M, Dieckman GS (1999) Biogeochemistry of Antarctic sea ice: a case study on platelet ice layers at Drescher Inlet, Weddell Sea. Mar Ecol Prog Ser 177:1-13

Haecky P, Jonsson S, Andersson A (1998) Influence of sea ice on the composition of the spring phytoplankton bloom in the northern Baltic Sea. Polar Biol 20:1-8

HELCOM (Helsinki Commission) (1988) Baltic Sea environment proceedings no. 27 D. Guidelines for the Baltic monitoring programm for the third stage. Baltic Marine Environment Protection Commission, Helsinki Commission, Helsinki

Hobbie JE, Daley RJ, Jasper S (1977) Use of nucleopore filters for counting bacteria by fluorescence microscopy. Appl Environ Microbiol 33:1225-1228

Horner RA (1985) Sea ice biota. CRC Press, Boca Raton, FL

Horner R, Schrader GC (1982) Relative contribution of ice algae, phytoplankton, and benthic microalgae to primary production in nearshore regions of the Beaufort Sea. Arctic 35:485-503

Horner RA, Ackley SF, Dieckman GS, Gulliksen B, Hoshiai T, Legendere L, Melnikov IA, Reeburg WS, Spindler M, Sullivan CW (1992) Ecology of sea ice biota. 1. Habitat, teminology, and methodology. Polar Biol 12:417-427

Ikävalko J (1997) Further observations on flagellates within sea ice in northern Bothnian Bay, the Baltic Sea. Polar Biol 19:323-329

Ikävalko J, Thomsen HA (1997) The Baltic Sea ice biota (March 1994): a study of the protistan community. Eur J Protistol 33:229-243 
Kirst GO, Wiencke C (1995) Ecophysiology of polar algae J Phycol 31:181--199

Kottmeier ST, Grossi SM, Sullivan CW (1987) Sea ice microbial communities. VIII. Bacterial production in annual sea ice of McMurdo Sound, Antarctica. Mar Ecol Prog Ser 35 $175-186$

Laurion I, Demers S, Vézina AF (1995) The microbial food web associated with ice the algal assemblage: biomass and bacterivory of nanoflagellate protozoans in Resolute Passage (High Canadian Arctic). Mar Ecol Prog Ser 120: $77-87$

Legendre L, Ackley SF, Dieckman GS, Gulliksen B, Horner R, Hoshiai T, Melnikov IA, Reeburgh WS, Spindler M, Sullivan CW (1992) Ecology of sea ice biota. 2. Global significance. Polar Biol 12:429-444

Maykut G (1985) The ice environment. In: Horner RA (ed) Sea ice biota. CRC Press, Boca Raton, FL, p 21-82

Mock T, Meiners KM, Giesenhagen HC (1997) Bacteria in sea ice and underlying brackish water at $54^{\circ} 26^{\prime} 50^{\prime \prime} \mathrm{N}$ (Baltic Sea, Kiel Bight). Mar Ecol Prog Ser 158:23-40

Nordström A, Wikner J (1996) The biology of the water column. In: Forsgren G, Wiklund K (eds) The Gulf of Bothnia 1996-annual report from the marine monitoring programme (in Swedish). Umeå Marine Sciences Centre, Luleá Alltryck, Luleå, p 11-12

Norrman B, Andersson A (1994) Development of ice biota in a temperate sea area (Gulf of Bothnia). Polar Biol 14: $531-537$

Palmisano AC, Garrison DL (1993) Microorganisms in Antarctic sea ice. In: Friedman IE (ed) Antarctic microbiology. Wiley-Liss, New York, p 167-218

Parsons TR, Maita Y, Lalli CM (1984) A manual of chemical and biological methods for seawater analysis. Pergamon Press, Toronto

Editorial responsibility: Tom Fenchel,

Helsinger, Denmark
Pelegrí SP, Dolan J, Rassoulzadegan F (1999) Use of high temperature catalytic oxidation (HTCO) to measure carbon content of microorganisms. Aquat Microb Ecol 16: $273-280$

Redfield AC, Ketchum BH, Richards FA (1963) The influence of organisms on the composition of sea water. In: Hill MN (ed) The sea. Wiley, New York, p 26-77

Rivkin RB, Putt M, Alexander SP, Meritt D, Gaudet L (1989) Biomass and production in polar planktonic and sea ice microbial communities: a comparative study. Mar Biol 101: $273-283$

Sakshaug E (1989) The physiological ecology of polar phytoplankton. In: Rey L, Alexander V (ed) 6th Conf Com Arct Int, 13-15 May 1985. EJ Brill, Leiden, p 61-89

Sanders RW, Caron DA, Berninger UG (1992) Relationships between bacteria and heterotrophic nanoplankton in marine and fresh waters: an inter-ecosystem comparison. Mar Ecol Prog Ser 86:1-14

Sime-Ngando T: Juniper SK, Demers S (1997) Ice-brine and planktonic microheterotrophs from Saroma-ko Lagoon, Hokkaido (Japan): quantitative importance and trophodynamics. J Mar Syst 11:149-161

Smith REH, Clement P (1990) Heterotrophic activity and bacterial productivity in assemblages of microbes from sea ice in the high Arctic. Polar Biol 10:351-357

Smith REH, Gosselin M, Kudoh S, Robineau B, Taguchi S (1997) DOC and its relationship to the algae in the bottom ice communities. J Mar Syst 11:71-80

Weeks WF, Ackley SF (1986) The growth, structure, and properties of sea ice. In: Understeiner $N$ (ed) Geophysics of sea ice. Plenum Press, NATO ASI Series 3, p 9-164

Wikner J, Hagström $\AA$ (in press) Bacterioplankton intra-annual variability: importance of hydrography and competition. Aquat Microb Ecol

Submitted: July 13, 1999; Accepted: October 28, 1999

Proofs received from author(s): December 7, 1999 